\title{
Efektivitas Pajak Bumi Bangunan Perdesaan Dan Perkotaan Terhadap Pendapatan Asli Daerah (PAD) Di Kabupaten Tasikmalaya
}

\author{
Taufik Wibisono $^{1}$,Yani Sri Mulyani ${ }^{2}$ \\ Universitas Bina Sarana Informatika, Kampus PSDKU Tasikmalaya \\ 1taufik.tik@bsi.ac.id \\ 2 yani.ymn@bsi.ac.id
}

\begin{abstract}
ABSTRAK
Dalam era otonomi daerah saat ini pemerintah membutuhkan dana yang cukup besar untuk memenuhi pembiayaan pemerintah dalam melaksanakan pembangunan daerah melalui Pendapatan Asli Daerah (PAD) yang merupakan sumber penerimaan daerah. Tujuan penelitian ini adalah untuk mengetahui tingkat efektivitas dan kontribusi Pajak Daerah terhadap PAD serta mengetahui pengaruh PBB terhadap PAD.Penelitian ini menggunakan metode deskriptif yang bertujuan untuk membuat deskripsi, gambaran, atau lukisan secara sistematis, faktual dan akurat mengenai fakta-fakta, sifatsifat serta hubungan antara fenomena yang diselidiki.Sumber data yang digunakan dalam penelitian ini adalah data sekunder dengan jenis data Time Series. Data sekunder yang digunakan yaitu Laporan Realisasi Anggaran Penerimaan Pajak Daerah Kabupeten Tasikmalaya tahun 2018.Efektivitas pajak bumi dan bangunan daerah terhadap pendapatan asli daerah berada pada kategori efektif, dengan kata lain bahwa tingkat efektifitas pajak bumi dan bangunan berada di angka 111,8\%.Kontribusi pajak bumi dan bangunan terhadap pendapatan asli daerah berada dalam katergori cukup baik dengan kata lain bahwa tingkat kontribusi pajak bumi dan bangunan berada pada angka 35,43\%.Hasil yang didapat sangat berpengaruh karena pendapatan dari PBB terhadap PAD melebihi dari target.
\end{abstract}

Kata kunci: efektivitas.pajak bumi dan bangunan, pendapatan

\begin{abstract}
In the current era of regional autonomy the government needs substantial funds to meet government funding in implementing regional development through Regional Original Revenue (PAD), which is a source of regional revenue. The purpose of reseach was to determine the level of effectiveness and contribution of Regional Taxes to PAD.This study used descriptive methods that aimed to make descriptions, drawings, or paintings systematically, factually and accurately regarding the facts, characteristics and relationships between the phenomena which was investigated.The data sources used in this research were secondary data with Time Series data types. Secondary data used was the Budget Realization Report for Tasikmalaya Regency Regional Tax Revenue in 2018. The effectiveness of the land and building tax on regional original income was in the effective category, in other words that the level of effectiveness of land and building tax is at 97\%.The contribution of land and building tax to regional original income was in the category 111,8\% in other words that the level of land and building tax contributions was in the numbers $35,43 \%$.
\end{abstract}

Keywords: effectiveness. Earth and building tax, income

Naskah diterima :11 Juli 2019, Direvisi:8 Agustus 2019 Naskah dipublikasikan : 16 September 2019

ISSN: 2355-0295, e-ISSN: 2549-8932 


\section{PENDAHULUAN}

Keberhasilan suatu bangsa dalam pembangunan nasional sangat ditentukan oleh kemampuan bangsa untuk dapat memajukan kesejahteraan masyarakat, daerah di Indonesia memiliki hak dan kewajiban mengatur dan mengurus sendiri pemerintahannya sebagai bentuk pembangunan ekonomi yang berbasis kemandirian, sumber sumber selanjutnya bergeser ke daerah, baik melalui perluasan berbasis pajak maupun dana perimbangan. Hal ini sejalan dengan makna desentralisasi fiscal yang mengandung pengertian bahwa kepada daerah diberikan kewenangan untuk memanfaatkan keuangan sendiri, yang dilakukan wadah Pendapatan Asli Daerah (PAD), dengan sumber utamanya adalah pajak daerah dan retribusi daerah.

Lahirnya (Undang-Undang Republik Indonesia Nomor 28 Tahun 2009 Tentang Pajak Daerah dan Retribusi Daerah, n.d.) merupakan implementasi atas lahirnya otonomi daerah yang diselenggarakan di Indonesia. Pajak daerah sebagai salah satu sumber Pendapatan Asli Daerah, merupakan sumber keuangan riil bagi pemerintah daerah. Suatu daerah mempunyai hak untuk mengatur, mendapatkan, dan memelihara aspek sumber Pendapatan Asli Daerahnya yang hasilnya $100 \%$ (seratus persen) dikelola oleh pemerintah daerah itu sendiri.

Penerapan (Undang-Undang Republik Indonesia Nomor 28 Tahun 2009 Tentang Pajak Daerah dan Retribusi Daerah, n.d.) telah mengubah sistem pengelolaan Pajak Bumi dan Bangunan khususnya sektor Perdesaan dan Perkotaan. Pajak Bumi dan Bangunan Perdesaan dan Perkotaan (PBB P2) yang awalnya merupakan pajak pusat kini menjadi pajak daerah. Pengalihan pengelolaan Pajak Bumi dan Bangunan Perdesaan dan Perkotaan (PBB-P2) dari Pemerintah Pusat kepada Pemerintah Daerah ini merupakan suatu bentuk tindak lanjut kebijakan otonomi daerah dan desentralisasi fiskal yang ada. Hasil dari pengelolaan pajak tersebut $100 \%$ (seratus persen) masuk ke kas daerah setempat, sehingga tidak akan ada lagi bagi hasil pajak kepada pemerintah pusat.

Banyak faktor yang mempengaruhi tingkat efektivitas pajak bumi dan bangunan diantaranya dengan adanya penyuluhan terhadap kolektor Pajak Bumi Dan Bangunan Perkotaan dan Perdesaan di tiap Kecamatan, faktor pengawasan oleh dinas yang membawahi pajak daerah, serta faktor penagihan.demi mencapai tingkat efektivitas penerimaan PBB P2 harus dibuat target atau rencana penerimaan supaya dapat tercapai hasil penerimaan seperti yang diharapkan oleh pemerintah daerah, target atau rencana penerimaan pajak bumi dan bangunan sangat penting karena sebagai titik awal menentukan besarnya jumlah pajak bumi dan bangunan yang harus dicapai dalam satu tahun pajak, dalam hal ini pemerintah daerah mempunyai peranan penting untuk mewujudkan target dan rencana penerimaan, karena sebagian besar hasil dari penerimaan pajak bumi dan bangunan yang di masukan kepada daerah digunakan untuk mengembangkan dan membangun daerahnya.

Efektivitas merupakan suatu ukuran untuk mengetahui berhasil atau tidaknya suatu organisasi dalam mencapai tujuan yang telah ditetapkan. Efektivitas adalah "ukuran berhasil tidaknya suatu organisasi mencapai tujuannya. Apabila suatu organisasi berhasil mencapai tujuan, maka organisasi tersebut dikatakan berjalan dengan efektif." (Mardiasmo, 2004) Tingkat efektivitas penerimaan PBB P2 dihitung berdasarkan hasil yang dicapai dengan target yang ditentukan. Semakin besar tingkat efektivitas penerimaan PBB P2, dapat dikatakan kinerja aparatur penegak pajak telah maksimal atau efektif dalam upaya mengoptimalkan penerimaan PBB P2 tersebut. Demikian pula sebaliknya, semakin kecil tingkat efektivitas yang dicapai maka kinerja aparatur penegak pajak kurang maksimal.Dari hasil penelitian ini diharapkan ini dapat bermanfaat untuk pihak-pihak terkait khususnya bagi: 
1. Pengembangan Ilmu Pengetahuan Hasil penelitian ini diharapkan menjadi tambahan khasanah ilmu pengetahuan dalam bidang manajemen sumber daya manusia khususnya mengenai efektivitas penagihan pajak bumi dan bangunan.

2. Aspek Guna Laksana

Hasil penelitian ini diharapkan dapat memberikan masukan yang bermanfaat untuk pengambilan kebijakan manajerial khususnya mengenai penagihan pajak bumi dan bangunan. Selain itu memberikan pengetahuan dan pengalaman sebagai masukan untuk penelitian selanjutnya.

3. Peneliti Lanjutan

Hasil penelitian ini diharapkan dapat memberikan masukan dan saran untuk penelitian lanjutan

Tujuan penelitian ini adalah untuk mengetahui dan menganalisis: Tingkat Efektivitas Pajak Bumi dan Bangunan terhadap pendapatan asli daerah (PAD) di Kabupaten Tasikmalaya pada Tahun 2018.

\section{KAJIAN LITERATUR Efektivitas}

Efektivitas adalah ukuran berhasil tidaknya suatu organisasi mencapai tujuannya. Apabila suatu organisasi berhasil mencapai tujuan, maka organisasi tersebut dikatakan telah berjalan dengan efektif (Mardiasmo, 2004). Efektivitas adalah mengukur hubungan antara hasil pungutan suatu pajak dengan potensi atau target penerimaan pajak itu sendiri. Efektivitas penerimaan Pajak Bumi dan Bangunan adalah mengukur hubungan antara hasil pungutan Pajak Bumi dan Bangunan dengan potensi atau target penerimaan Pajak Bumi dan Bangunan.

Hasil tersebut sejalan dengan penelitian yang dilakukan (Saputro, Sudjana, \& Azizah., 2014) Tingkat efektivitas penerimaan PBB Perkotaan Surabaya pada saat dikelola oleh DJP menunjukkan hasil lebih baik dibandingkan pada saat PBB tersebut dikelola oleh DPPK Kota Surabaya. Hal tersebut dapat dilihat berdasarkan rata-rata efektivitas penerimaan PBB Perkotaan pada saat dikelola oleh DJP (2009-2010) dan rata-rata efektivitas penerimaan pada saat dikelola oleh DPPK Kota Surabaya (2011-2013). Rata-rata efektivitas penerimaan PBB Perkotaan Surabaya pada saat dikelola DJP sebesar $86,45 \%$ dengan kriteria nilai interptretasi cukup efektif, sedangkan rata-rata efektivitas penerimaan PBB Perkotaan Surabaya pada saat dikelola oleh DPPK sebesar 76,38\% dengan kriteria nilai interpretasi kurang efektif.

\section{Pajak}

Pengertian Pajak

Definisi menurut. Rochmat Soemitro dalam (Suandy, 2015) Pajak adalah iuran kepada kas negara berdasarkan undang-undang (yang dapat dipaksakan) dengan tidak mendapat jasa timbal (kontra prestasi) yang langsung dapat ditunjukkan dan yang digunakan untuk membayar pengeluaran umum. Definisi tersebut disempurnakan menjadi "Pajak adalah peralihan kekayaan dari pihak rakyat kepada kas Negara untuk membiayai pengeluaran rutin dan "surplus"-nya digunakan untuk public saving yang merupakan sumber utama untuk membiayai public investment".

\section{Pendapatan Asli Daerah}

"Pendapatan Asli Daerah (PAD) adalah penerimaan yang diperoleh daerah dari sumber-sumber dalam wilayahnya sendiri yang dipungut berdasarkan peraturan daerah sesuai dengan peraturan perundang-undangan yang berlaku (Halim, 2004). Sektor pendapatan daerah memegang peranan yang sangat penting, karena melalui sektor ini dapat dilihat sejauh mana suatu daerah dapat membiayai kegiatan pemerintah dan pembangunan daerahnya sendiri. Daerah dituntut untuk berperan aktif dalam mengoptimalkan penerimaan pendapatan daerahnya. Hal tersebut sebagai upaya untuk menggali pendanaan dalam pelaksanaan otoda (otonomi daerah) sebagai perwujudan asas desentralisasi. Hal ini terbalik dengan penelitian yang dilakukan oleh (Hassanudin., 
2014) Kontribusi pajak atas kendaraan bermotor terhadap penerimaan pendapatan asli daerah diprovinsi Maluku Utara adalah kurang baik hal ini menunjukan bahwa pemerintah daerah Provinsi Maluku Utara dalam hal ini Dinas Pendapatan dan Pengelolaan Aset Daerah Provinsi Maluku Utara kurang serius mengidentifikasi, menggali, dan mengoptimalkan sejumlah objek pajak lainnya yang menjadi objek pajak kendaraan bermotor untuk ditetapkan dan dipungut sebagai pajak atas kendaraan bermotor

\section{Pajak Daerah}

Pajak Daerah adalah pungutan wajib atas orang pribadi atau badan yang dilakukan oleh pemerintah daerah tanpa imbalan langsung yang seimbang, yang dapat dipaksakan berdasarkan peraturan perundang-undangan yang berlaku, yang digunakan untuk membiayai penyelenggaraan pemerintah daerah dan pembangunan daerah (Prakosa \& Kesit, 2005).

\section{Pajak Bumi Dan Bangunan \\ Pengertian Pajak Bumi dan Bangunan}

Berdasarkan (Undang-Undang Republik Indonesia Nomor 12 Tahun 1994 Tentang Pajak Bumi dan Bangunan, n.d.). Pajak Bumi dan Bangunan (PBB) adalah pajak yang bersifat kebendaan dalam arti besarnya pajak terutang ditentukan oleh keadaan objek yaitu bumi/tanah dan atau bangunan. Keadaan subyek (siapa yang membayar) tidak ikut menentukan besarnya pajak. Pengertian PBB adalah iuran yang dikenakan terhadap pemilik, pemegang kekuasaan, penyewa dan yang memperoleh manfaat dari bumi dan bangunan. Pengertian bumi adalah permukaan bumi dan tubuh bumi yang ada dibawahnya. Bumi menunjuk pada permukaan bumi meliputi tanah dan perairan pedalaman serta laut wilayah Indonesia. Bangunan adalah konstruksi teknik yang ditanam atau diletakan secara tetap pada tanah dan perairan dengan digunakan sebagai tempat tinggal atau tempat berusaha.(Diana \& Setiawati, 2009)
Hasil tersebut sejalan dengan penelitian yang dilakukan (Prathiwi, Herawati, \& Sulindawati, 2014) Penerimaan Pajak Bumi dan Bangunan Pedesaan dan Perkotaan (PBB P2) Kota Denpasar dari tahun 2011 hingga 2014 sangat efektif. Hal ini dilihat dari tingkat efektivitas penerimaan PBB melebihi $100 \%$. Hal ini berarti bahwa target yang telah ditetapkan sebelumnya oleh pemerintah selalu tercapai.

\section{Objek PBB}

Objek Pajak Bumi dan Bangunan adalah Bumi dan atau Bangunan. Bumi adalah permukaan bumi dan tubuh bumi yang ada di bawahnya. Permukaan bumi meliputi tanah dan perairan pedalaman (termasuk rawa-rawa, tambak, perairan) serta laut wilayah Republik Indonesia. Sedangkan bangunan adalah konstruksi teknik yang ditanam atau dilekatkan secara tetap pada tanah dan atau perairan. (Mardiasmo, 2009)

\section{Subjek PBB}

Subjek Pajak dalam Pajak Bumi dan Bangunan adalah orang pribadi atau badan yang secara nyata mempunyai suatu hak atas bumi, dan/atau; memiliki, menguasai atas bangunan, dan/atau; memperoleh manfaat atas bangunan(Waluyo, 2009)

Diharapkan dengan adanya Pajak semua orang akan mengerti dan membayar pajak sehingga ini sangat mendukung bagi pembangunan daerahnya. Hal ini sejalam dengan penelitian yang dilakukan oleh (Fajar, 2013) bahwa pelaksanaan pemeriksaan pajak memiliki pengaruh terhadap kepatuhan Wajib Pajak Badan. Hasil penelitian yang dilihat dari berbagai persepsi yaitu persepsi petugas pemeriksa pajak, persepsi Wajib Pajak, dan persepsi gabungan antara petugas pemeriksa dan Wajib Pajak.

Selain itu juga bahwa pelaksanaan pemeriksaan pajak dapat memberikan kontribusi yang positif dalam meningkatkan kepatuhan wajib pajak dan berimplikasi pada penerimaan pajak yang optimal. 


\section{METODE PENELITIAN}

Penelitian ini menggunakan metode deskriptif yang bertujuan untuk membuat deskripsi, gambaran, atau lukisan secara sistematis, faktual dan akurat mengenai fakta-fakta, sifatsifat serta hubungan antara fenomena yang diselidiki.

metode deskriptif adalah suatu metode yang berfungsi untuk mendeskripsikan atau memberi gambaran terhadap objek yang diteliti melalui data atau sampel yang telah terkumpul sebagaimana adanya tanpa melakukan analisis dan membuat kesimpulan yang berlaku untuk umum. (Sugiyono, 2009)

Dengan kata lain penelitian deskriptif analisis mengambil masalah atau memusatkan perhatian kepada masalah-masalah sebagaimana adanya saat penelitian dilaksanakan, hasil penelitian yang kemudian diolah dan dianalisis untuk diambil kesimpulannya.

Metode penelitian kualitatif sering disebut sebagai metode penelitian naturalistik karena penelitiannya dilakukan dalam kondisi yang alamiah (natural setting); disebut juga sebagai metode etnographi, karena pada awalnya metode ini lebih banyak digunakan untuk penelitian bidang antropologi budaya; disebut kualitatif, karena data yang terkumpul dan analisisnya lebih bersifat kualitatif. Metode penelitian kualitatif adalah metode penelitian yang berlandaskan pada filsafat postpositivisme, digunakan untuk meneliti pada kondisi obyek yang alamiah, (sebagai lawannya adalah eksperimen) dimana peneliti adalah sebagai instrumen kunci, analisis data bersifat induktif/kualitatif, dan hasil penelitian kualitatif lebih menekankan pada makna generalisasi (Sugiyono, 2009) Berdasarkan pendapat di atas, yang dimaksud dengan penelitian kualitatif deskriptif yaitu bahwa sebuah penelitian kualitatif akan menggambarkan suatu fenomena tertentu dalam setting naturalnya yang dijabarkan dalam katakata tertulis, sehingga peneliti akanmendeskripsikan suatu keadaan tertentu dari fakta yang terjadi pada proses penelitian, baik yang berupa perilaku, persepsi, motivasi, tindakan dan yang lainnya tanpa memanipulasi fenomena yang diamati. Peneliti menggunakan pendekatan penelitian ini karena sesuai dengan jenis penelitian yang akan dilakukan, yaitu untuk mendeskripsikan tentang efektif atau tidaknya Pemungutan Pajak Bumi dan Bangunan yang dilakukan oleh Badan Pengelolaan Pendapatan Daerah Kabupaten Tasikmalaya.

\section{Sumber dan jenis data penelitian}

Sumber data yang digunakan dalam penelitian ini adalah data sekunder dengan jenis data Time Series.Data sekunder yang digunakan yaitu Laporan Realisasi Anggaran Penerimaan Pajak Daerah Kabupeten Tasikmalaya tahun 2018.

\section{Metode Analisis Data}

(Sujarweni, 2014) menyatakan bahwa analisis data dapat diartikan sebagai cara melaksanakan analisis terhadap data, dengan tujuan mengolah data tersebut untuk menjawab rumusan masalah. Metode analisis data yang digunakan adalah metode analisis deskriptif kuantitatif.

\section{Definisi dan Pengukuran Variabel Operasional}

Efektivitas adalah ukuran berhasil tidaknya suatu organisasi dalam mencapai tujuannya (Mardiasmo, 2011). Apabila organisasi berhasil mencapai tujuan, maka organisasi tersebut dapat dikatakan telah berjalan dengan efektif. Rumus perhitungan efektivitas

Efektivitas $=$ Realisasi Penerimaan Pajak Daerah $\mathrm{X}$ $100 \%$ Target penerimaan pajak Daerah

(Halim,2004:135)

Guna mengetahui efektif atau tidaknya pajak terhadap penerimaan pendapatan asli daerah dapat diukur dengan menggunakan kriteria dan indikator dibawah ini. 
Tabel 1 .Kriteria Efektivitas Penerimaan Pajak Daerah.

\begin{tabular}{ll}
\hline \multicolumn{1}{c}{ Presetasi Efektivitas } & \multicolumn{1}{c}{ Kriteria } \\
\hline Diatas $100 \%$ & Sangat Efektif \\
\hline $90-100 \%$ & Efektif \\
\hline $80-90 \%$ & Cukup Efektif \\
\hline $60-80 \%$ & Kurang Efektif \\
\hline Kurang Dari 60\% & Tidak Efektif \\
\hline sumber: Depdagri, & Kepmendagri No. \\
690.900.327 dalam (Puspitasari, Elfayang, \& \\
Ayu, 2014)
\end{tabular}

Guna mengetahui bagaimana dan seberapa besar kontribusi Pajak Daerah terhadap Pendapatan Asli Daerah dengan menggunakan kriteria sebagai berikut:

Tabel 2.Presentasi Kriteria

\begin{tabular}{|l|}
\hline Persentase Kriteria \\
\hline $0,00 \%-10 \%$ Sangat kurang \\
\hline 10,10\%-20\% Kurang \\
\hline $20,10 \%-30 \%$ Sedang \\
\hline $30,10 \%-40 \%$ Cukup baik \\
\hline 40,10\%-50\% Baik \\
\hline Di atas 50\% Sangat baik \\
\hline
\end{tabular}

Sumber:Depdagri,Kepmendagri

No.690.900.327 .(Hassanudin., 2014)

\section{Pendapatan Asli Daerah}

Pendapatan Asli Daerah (PAD) adalah pendapatan yang diperoleh daerah dan dipungut berdasarkan peraturan daerah sesuai dengan peraturan perundangundangan.(Siahaan, 2005)

\section{PEMBAHASAN}

1. Analisis Efektivitas Pajak Daerah Terhadap Pendapatan Asli Daerah

Untuk mengetahui sejauhmana Efektivitas Pajak Daerah Terhadap Pendapatan Asli Daerah di Kabupaten Tasikmalaya.

Untuk mengetahui seberapa tingkat efektivitas pajak daerah terhadap pendapatan asli daerah
(PAD) maka perlu dilakukan analisis efektivitas pajak daerah terhadap realisasi penerimaan pendapatan asli daerah (PAD).

Pada tahun 2018 potensi pajak bumi dan bangunan di Kabupaten Tasikmalaya sebesar Rp.21,084,370,713 dan target pajak bumi dan bangunan di Kabupaten Tasikmalaya tahun 2018 adalah Rp.18,520,000,000 sedangkan realisasi tahun 2018 sebesar Rp.20,700,315,695 jika berdasarkan pada indicator efektivitas maka penilainnya adalah sangat efektif. Karena tingat efektivitaspajak bumi dan bangunan

di Kabupaten Tasikmalaya adalah sebesar $111,8 \%$.

\section{Analisis Kontribusi Pajak Daerah Terhadap Pendapatan Asli Daerah}

Guna mengetahui seberapa besar kontribusi pajak daerah terhadapPendapatan Asli Daerah (PAD) maka perlu dilakukan analisis realisasipenerimaan kontribusi pajak daerah terhadap realisasi penerimaanPendapatan Asli Daerah (PAD).

Pada tahun 2018 kontribusi pajak daerah terhadap pendapatan daerah adalah sebesar 35,43 jika berdasarkan pada kriteria atau indicator diatas maka penilaiannya adalah cukup baik.

\section{Analisis Efektivitas Pajak Daerah Terhadap Pendapatan Asli Daerah}

Tabel 3.Analisis Kontribusi Pajak Daerah Terhadap Pendapatan Asli Daerah

\begin{tabular}{lllll}
\hline $\begin{array}{l}\text { Ta } \\
\text { hu } \\
\text { n }\end{array}$ & $\begin{array}{l}\text { Target } \\
\text { Pajak } \\
\text { Daerah }\end{array}$ & $\begin{array}{l}\text { Realisasi } \\
\text { PBB }\end{array}$ & $\begin{array}{l}\text { Perse } \\
\text { ntasi }\end{array}$ & $\begin{array}{l}\text { Kriteri } \\
\text { a }\end{array}$ \\
\hline 20 & $58,426,606$, & $20,700,31$ & 35,43 & Cukup \\
18 & 032 & 5,695 & & Baik \\
\hline
\end{tabular}

Tabel 3 memperlihatkan bahwa kontribusi pajak bumi dan bangunan pada tahun 2018 adalah sebesar 35,43. Hal tersebut menunjukkan bahwa pemungutan pajak daerah pada tahun 2018 adalah cukup baik. 
Tabel 4 .Analisis Efektivitas Pajak Daerah

Terhadap Pendapatan Asli Daerah

\begin{tabular}{lllll}
\hline $\begin{array}{l}\text { Ta } \\
\text { Hun }\end{array}$ & Target & Realisasi & $\begin{array}{l}\text { Persent } \\
\text { asi }\end{array}$ & $\begin{array}{l}\text { kriteri } \\
\text { a }\end{array}$ \\
\hline $\mathbf{2 0}$ & 18,520 & $20,700,31$ & $111,8 \%$ & sangat \\
$\mathbf{1 8}$ & $, 000,0$ & 5,695 & & efektif \\
& 00 & & & \\
\hline
\end{tabular}

Tabel 4 memperlihatkan bahwa pemungutan pajak bumi dan bangunan pada tahun 2018 adalah sebesar 111,8\%. Hal tersebut menunjukan bahwa pemungutan pajak daerah pada tahun 2018 adalah sangat efektif.

\section{PENUTUP}

Efektivitas pajak bumi dan bangunan daerah terhadap pendapatan asli daerah berada pada kategori efektif, dengan kata lain bahwa tingkat efektifitas pajak bumi dan bangunan berada di angka 111,8\%. Kontribusi pajak bumi dan bangunan terhadap pendapatan asli daerah berada dalam katergori 35,43 dengan kata lainbahwa tingkat kontribusi pajak bumi dan bangunan berada pada angka cukup baik.

\section{REFERENSI}

Diana, A., \& Setiawati, L. (2009). Perpajakan indonesia (3rd ed.). yogyakarta: andi.

Fajar, C. M. (2013). Pengaruh Pelaksanaan Pemeriksaan Pajak terhadap Kepatuhan Wajib Pajak Badan Berdasarkan Persepsi Pemeriksaan Pajak dan Wajib Pajak. Jurnal Ekonomi, Manajemen Dan Bisnis (Ecodomica, 1 no 3. Retrieved from https://ejournal.bsi.ac.id/ejurnal/index.p hp/ecodemica

Halim, A. (2004). akuntasi keuangan daerah. jakarta: salemba empat.

Hassanudin. (2014). Analisis Efektivitas dan Kontribusi Pajak Kendaraan Bermotor
Terhadap Penerimaan Pendapatan Asli Daerah Di Provinsi Maluku Utara. Accountability, 3 no 1. Retrieved from https://ejournal.unsrat.ac.id/index.php/a ccountability/article/view/4941

Mardiasmo. (2004). Otonomi dan Manajemen Keuangan Daerah (2009th ed.). yogyakarta: andi.

Mardiasmo. (2009). Akuntansi Sektor Publik (2009th ed.). Yogyakarta: Andi.

Mardiasmo. (2011). Perpajakan Edisi Revisi. Yogyakarta: andi.

Prakosa, B., \& Kesit. (2005). Hukum Perpajakan (2006th ed.). Yogyakarta: Ekonisia Fakultas Ekonomi UII.

Prathiwi, I. A. M. A., Herawati, N. T., \& Sulindawati, N. L. G. E. (2014). Analisis Strategi Penerimaan Pajak Bumi dan Bangunan Pedesaan dan Perkotaan (PBB P2) serta Efektivitas Penerimaannya di Pemerintah Kota Denpasar. Jurnal Akuntansi Program, 3 No 1.

Puspitasari, Elfayang, \& Ayu, R. (2014). Analisis Efektivitas, Efisiensi, Dan Kontribusi Pajak Dan Retribusi d aerah Terhadap PAD Kabupaten Blora ahun 2009-2013. Diponegoro Semarang.

Saputro, R., Sudjana, N., \& Azizah., D. F. (2014). Efektivitas Penerimaan Pajak Bumi dan Bangunan Perdesaan dan Perkotaan (PBB-P2) terhadap Peningkatan Penerimaan Pendapatan Asli Daerah (PAD) (Studi pada Dinas Pendapatan dan Pengelolaan Keuangan Kota Surabaya. Jurnal Mahasiswa Perpajakan, 2 nol.

Siahaan. (2005). Pajak Daerah dan Retribusi Daerah. Jakarta: Raja Grafindo Persada.

Suandy, E. (2015). hukum pajak (5th ed.). jakarta: salemba empat.

Sugiyono. (2009). Metode Penelitian Bisnis 
(Pendekatan Kuantitatif, Kualitatif, dan $R \& D)$. Bandung: Alfabeta.

Sujarweni, V. W. (2014). Metode Penelitian: Lengkap, Praktis, dan Mudah Dipahami. Yogyakarta: Pustaka Baru Press.

Undang-Undang Republik Indonesia Nomor 12 Tahun 1994 Tentang Pajak Bumi dan Bangunan. (n.d.).

Undang-Undang Republik Indonesia Nomor 28 Tahun 2009 Tentang Pajak Daerah dan Retribusi Daerah. (n.d.).

Waluyo. (2009). Perpajakan Indonesia (8th ed.). Jakarta: Salemba Empat.

\section{BIODATA PENULIS}

Taufik Wibisono, lahir di Tasikmalaya 8 September 1990, Pendidikan S1 Universitas Siliwangi jurusan Tekhnik Informatika lulus tahun 2013 Sarjana S2 di Universitas Siliwangi jurusan Manajemen lulus tahun 2017. Dosen Universitas Bina Sarana Informatika Kampus Tasikmalaya 2015 sd sekarang.

Yani Sri Mulyani Lahir di Tasikmalaya 28 Mei 1968 pendidikan sarjana S1 bahasa Inggris di STBA Yapari Bandung lulus tahun 1993,Sarjana S2 Magister Manajemen di Universitas BSI Bandung lulus tahun 2014. Dosen Universitas Bina Sarana Informatika Kampus Tasikmalaya 2004 sd sekarang. Karya ilmiah yang dihasilkan :The Role of Marketing in Tjiwulan Embroidery of Kawalu Tasikmalaya in Developing Tourist Industry.Pengaruh Pendidikan dan Pelatihan Entrepreneurship terhadap Motivasi Berwirausaha Mahasiswa.Selain itu, mengikuti kegiatan seminar-seminar dan menjadi narasumber seminar dan workshop. 